\title{
農作業の人間工学的解析
}

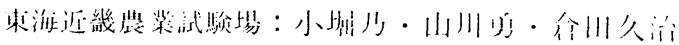

\begin{abstract}
Osamu KOBORI, Isamu YAMAKAWA, and Hisaharu KURATA:
On Ergonomical Analysis of Farm Work.
\end{abstract}

機械化されない農業では本来単位面積当り所要労 力も多く、激しい、長時間斬続した労働を必要とす る場合が多い。にもかかわらず、作業者の質はさし て問題にされない場合が多い。機械化された農業で は単位面積当り所要学力は、はるか、少なくなるが、 一方では、体力もあり、熟練した良質の作業者炕よ る作業が要求されている場合が多いが、これはどう ららことであろうか。流動しつつある農業人口のな かからこのよらな作業者を今後とも確保し続けると とがでをるのだろらか。農業近代化には、作業者の 面からみて、どのよらな問題があるのだろらか。

ともあれ、農業労働力は減少し、老人化、婦人化 の傾向をたどるという。とくに、東海近畿地域のよ ら洰巨带都市地带周辺の農業地带を多く含む地域で の労㗢力の減少は著るしんととが予想されている。 農業労働力は、将来、どのように変化してゆくのだ ろらか。

そのよらな、作業者の量的、質的な変化を考慮し た上で、作業体系を策定し、しかも、作業者の労働 意欲に満ちたものであるためには、どのような考え 方を基準にせね悋ならないのだろらか。

筆者たちは、とくに第 3 の問顥を解決するには、 人間工学的な考方方を導入する必要があると考充、 農作業における人間工学の位置づけについて検討し てをた（小堀、1968）が、本論では、上記 $3 つ$ の疑問に対する筆者たちなりの解答といら形で整理 を試み、諸賢の御批判をあお妾たい。

\section{1. 人間・株機械}

農業㟔、機械化されている場合であっても、機械 化されていない場合であっても、常て不測の事態に らたる可能性を含んでいる。てれは、農業の機械化 が農業の近代化といえるためには、無視でさない問

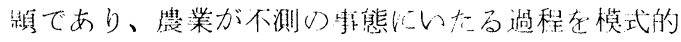

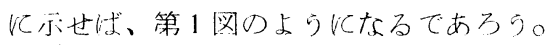

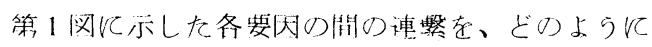
し、て断七切るか、どの䡛慗䘮断ち切るかが問題であ るが、断ち切るための手段を考えるには、人間・機 械系の解析という立場からの検討が必要となってく る。

垷在屯での研究例では、多くの場合は、機械構造 上の改良といら見地から、人間・機械系の解析がな されている。たとえば、Bellinger（1969）氏は、 人間工学的な配㴔のはらわれた農業機械の条件とし て、作業能率の高いとと、作業者の出力が少なくて よいとと、精度の高いとと、安全性の高いとと、許 容度の高いとと、快適性の高いとと、作業者の技能 を充分生かすととがでをるとと、をあげており、S一 uggs（1969）氏江人間・機械・環境系といら考完 方から、配虑老はらら必要のある作業環境条件とし て、騒音、振動、安全性、作業機の放熱の影響、操

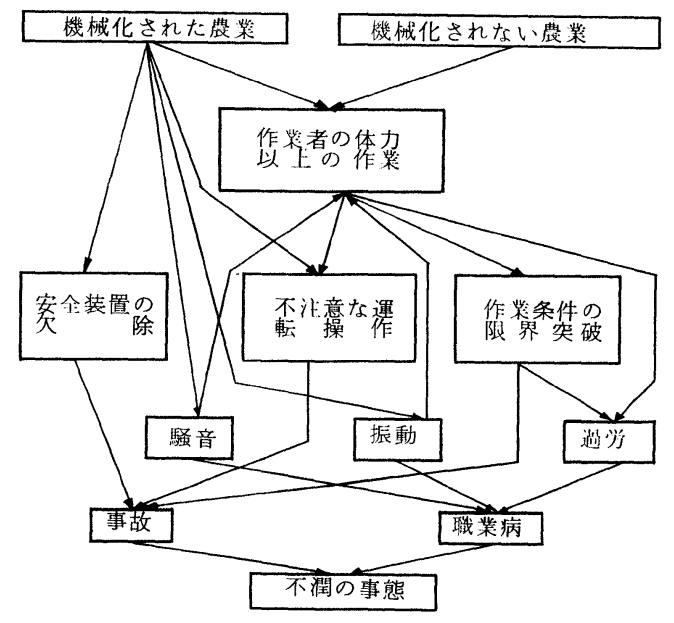

第1図農作業における不測の事

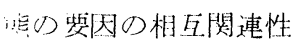


作の迅速性、をあげている。てのよらな、農業機械 の条件あるいは作業環境条件党農作業法の条件とし て、その京置をかえることがでをる。しかし、作 業法につんての同様の考察は、潘とんど見当らない。 ところが、第 1 図によれば、機械改良といら手段に よら权ば斬繫を切ることがでをない項目は、”安全 装置の久除"とんら項目だけで、あとの項目につい ては、機械改良以外の手段でも解決でさる場合があ る。いんかえれば、作業法の改良といら手段で、人 間・機械系孝、より作業者に適したものにでをる場 合が多いと考允られ、屯た、機械条件が充分満足さ れていたとしても、作業法の改良とより、一層作業 者に適したものにでさる場合が多いと考えられる。 しかし、そのためには、作業が作業者に適している か否かを判定するための基準が必要であり、その前 に、農業の基幹労力となる作業者は、質的にどの程 度を標準と考え朴ばならか、について一応の目や すを立て枚ばならぬ。

\section{2. 地域農業の免幹労力}

好屯し々人間・機械系沅、機械の側のみから接近 しょうとすれば、経済的に一つの限界がある。逆に 人間の側のみから接近しよらとすると、困難な作業、 機械化作業は青壮年男子労働で、といらことになる が、これも限界がある。たとえば、東海近畿地域農 業につんて、基幹労力の中で青壮年男子の占める割

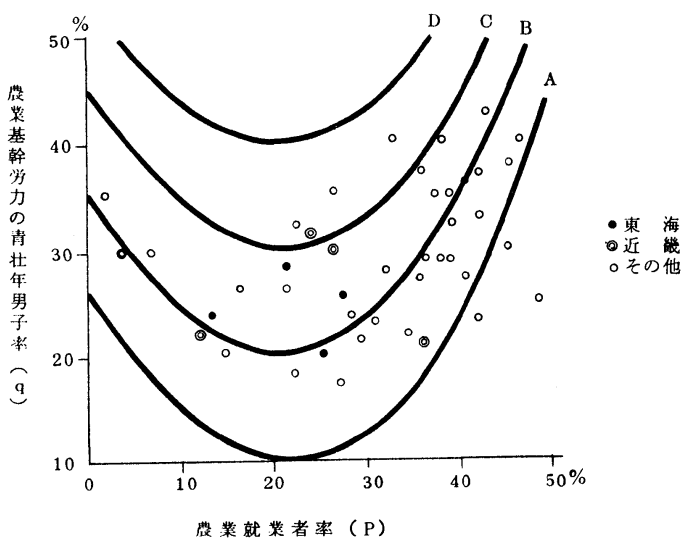

第2図各県の農業就業者率と農業 基幹労力の青壮年男子摔
合は決して高いといえず、今後も高くないととが推 定される。その点について、第2図により説明しょ 5。

第 2 図は、各県の農業就業者率と、農業基幹労力 の中で占める青壮年男子の比率との関係を示したも のである。図から農業就業者率の高い県は、農業基 幹学力の中で占兴青壮年男子の比率も高いが、農 業就業者率の低い県は、農業基幹労力の中で占める 青壮年男子の此率も低い傾向が認められたが、極端 に農業就業者率の低い県では、むしろ農業基幹労力 の中で占める青壮年男子の比率は高くなっている。 そして、最も青壮年男子の比率の低いのは、農業就 業者率 $20 \%$ 前後の県であることが推察された。こ のよらに、農業就業者率と農業基幹労力の中で占的 る青壮年男子の比率との間に一定の傾向が認められ た理由はともかくとしても、農業就業者率が変化す れば、それにともなって、農業基幹労力の中で占め る青壮年男子の比率も、一定の傾向で変化するとと が推祭されるのである。

したがって、農業就莱者率を $\mathrm{p}$ 、農業基幹労力の 中で青壮年男子（ $16 \sim 50$ 才）の占める割合を q と すれば、 $\mathrm{p}$ と $\mathrm{q}$ との関係は、第 2 図の曲線 $\mathrm{B} て ゙$ 表現 するととがでをる。これを教理的に表現すれば、

$$
\mathrm{q}=\mathrm{f}(\mathrm{p}) \fallingdotseq 0.04 \mathrm{p}^{2}-1.50 \mathrm{p}+35.00
$$

で近似するととがでをる。分散の範囲を考慮すれば、 第 2 図の曲線 $\mathrm{A} \sim \mathrm{C}$ の範囲で表現するととがでをる 加、

$$
q=0.04 p^{2}-1.50 p+35.00 \sim 55.00
$$

となる。将来壮、 $\mathrm{q}$ の上限に近い基幹労力を有する 場合が専業化してゆくと仮定してみると、分散の範 囲も考虑すれば、第 2 図の曲線B～Dの範囲で表現 することがでをるから、

$$
\mathrm{q}=0.04 \mathrm{p}^{2}-1.50 \mathrm{p}+35.00 \sim 55.00
$$

となる。乙れと東海近畿地域各府県をあてはめれば、 現在の東海近畿地域各府県は、

$$
\mathrm{p}=3 \sim 35
$$

の範囲にある。したがって、

$$
\mathrm{q}=30 \sim 20
$$

すなわち、現在は 20 ～30\%を青壮年男子労働者に 期待し、残りの $70 \sim 80 \%$ は老弱労㗢力に期待して レることになる。さらに、10 年後は 
$\mathrm{p} \rightarrow \frac{2}{3} \mathrm{p}$

と仮定すれ壮、

$$
\mathrm{p}=2 \sim 20
$$

であるから、

$$
q=42 \sim 30
$$

となる。すなわち、将来を考えても、30〜 40\%青 壮年男子労働者に期待し、残りの60 70\%は老弱労 働力に期待せねばならぬととが推定でをる。

このよらな推定の結果、東海近畿地域の農業の基 幹労力平均的にみれば、現在は、青壮年男子 1 人 に対して、老弱労働者 $3 \sim 4$ 人といら組作業人員構 成が、将来。、青壮年男子 1 人に対して、老弱労働 者 2 〜 人といら組作業人員構成が、それぞれ、標 準組作業人員と考えられる。したがつて、標準組作 業人員を想定する場合壮、青壮年男子 1 人之老弱労 働者 3 人を単位と考えるのが妥当であろら。そして、 作業法が作業者に適しているか否かを判定するには、 作業者を上記のよらな組作業人員構成と想定して判 定の基準を考えねばならぬであろら。

\section{3. 組作業人員}

このよらな人員構成からなりたつ組作業人員が、 労動意欲に満ちて作業できる作業体系を策定するに は、作業者の体力、能力を充分考慮した、周到な作 業分担計画と、作業者の体力に応じて適当な休息を 与える、計画性に满ちた作業時間計画の設定が必要 である。その場合、各作業の組作業人員は、流れ作 業を円滑に行ならために最適な人員として設定する だけではなく、作業者に適当な休息を与えるための 作業交代要員としての考え方を含めて設定しなけれ ばならなん。といらことは、作業組人員によって、 想定される作業能率がことなるといらととになる。 たとえば、作業時間に対する作業後必要休息時間の 割合 (休息・作業時間比率) と組作業人員がかわれ ば、機械の作業能率がどのよらと変化するかにつん て、極く簡単な計算を試みれば、第 3 図のよらにな る。

第3 図に明らかなよらに、組作業人員を増すとと によって、機械自体の作業能率は充分発揮でをるが、 所要労力につんてみれば、必ずしも有利とはんえな ん。 しかし、限られた期間に必要な面積を作業し終

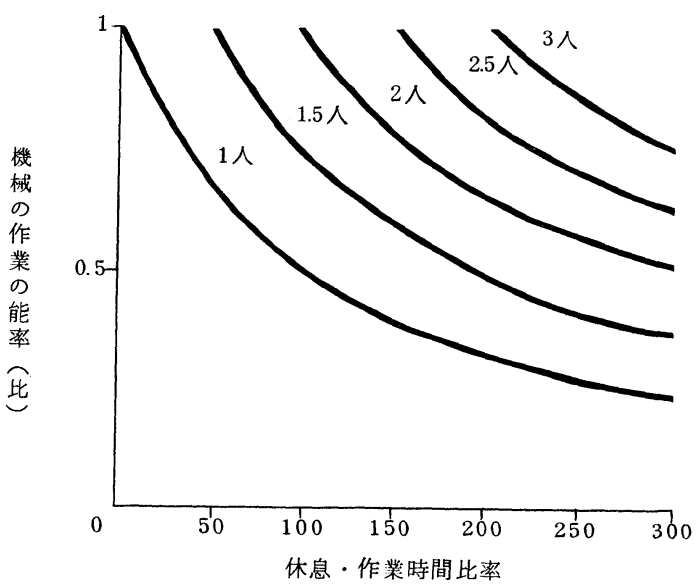

第3図休息作業時間比率と組作業人員

るためには、機械の作業能率を充分発揮するととが 必要であり、そのためには組作業人員を増さねばな らない場合も当然考えられ、経済性からみても最も 有利であり、かつ、作業スケシュール上作業者僙 理のない組作業人員が設定されねばならない。この 場合、組作業人員に応じた作業法、作業機の選定が 必要であり、やむ在えず休息を多く要する困難な作 業で、充分機械の作業能率を高めよらとすれば、組 作業人員を増さなければならない。組作業人員が限 定されている場合は、作業能率を高く見つもり過ざ ならととが必要である。

しかし、どのよらにして組作業人員とその機械に 応じて、適当と考えられる作業能率を見出すかにつ らての基礎資料は、残念ながら極めて少ない。しか し、前述のよらに東海近畿地域の農業においては、 どのよらな作業法からなる作業体系を想定するかに ついて、どのよらな組作業人員を前提とするかを無 視しては、きめ難い場合が多い。このよらと組作業 人員が作業法を決定するといらととは、どのような 農業集団を作るかで農法がことなるといらととであ り、逆㣗んえば、適当な農業集団さえ作られれば、 近代化された農法の導入が極めて容易であるといら ことでもあり、適当な行政措置さえ得られれば、高 度に集団化され、近代化された農業が育ちらる素地 在もっともんえよ5。

このような見通しに立つ時、現在の東海近畿地域 の農作業研究で急がれるのは、作業者が充分な労働 
意欲をもって農作業にはげめるためとは、慣行ある い致行の作業体系の中でどのような作業がネック となるか、作業体系を構成する各作業の中でどのよ らな操作がネックとなるかを見出すととがまず必要 であり、同時に、各作業について、作業と休息時間 につんての時間設計の基準を明らかにすることが必 要であり、そのような作業時間設計を効果的に進め るための作業分担計画の基準を明らかとするととが 必要である。

筆者たちは、このような考え方にもとづいて、現
在、一方では作業の強さなど作業の快適性の面から、 他方では騒音、振動など作業環境の快適性の面から 検討し、作業体系の中の人間工学的なネックとなる 作業、作業の中でネックとなる操作を摘出し、同時 飞各作業につ的て、作業・休息時間設計の基淮を明 らかとするための人間工学的な解析を試みている。 研究は緒につい注かりであるが、以、基本となる 考方方について披歴し、諸賢の御批判をあおぐ次第 である。 